\title{
Plankton Biomass in Secondary Ponds Treating Piggery Waste
}

\author{
Lígia Barthel, Paulo Armando Victória de Oliveira and Rejane Helena Ribeiro da Costa* \\ Departamento de Engenharia Sanitária e Ambiental; Campus Universitário; rejane@ens.ufsc.br; 88010-970; \\ Florianópolis - SC - Brasil
}

\begin{abstract}
This study aimed at analyzing the plankton biomass found in a piggery waste treatment system, composed of a high rate algal pond (HRAP), two maturation ponds (MP1, MP2) (System A) and a water hyacinth pond (WHP) (System $B)$. The ponds were disposed in series and the study was performed for 32 weeks. The physicochemical variables monitored were: $\mathrm{pH}$, temperature, dissolved oxygen, soluble chemical oxygen demand, nitrogen compounds and total phosphorus. The plankton biomass was identified at genus level and the ecology index was calculated so as to describe its development in the ponds. Results showed lower specific richness, which was associated to the monospecific Chlorella sp population. The protozoa density was conversely proportional to the green algae density. The higher species diversity occurred in the WHP and MP2. The green algae presented high relative density (>97 \%). The Jaccard index reached $100 \%$ if Chlorella sp and sometimes diatoms were found in the system's inlet and outlet. The productivity of algal biomass was lower than $10 \mathrm{gTSS} / \mathrm{m}^{2} / d$ in the maturation ponds, which was maintained in the HRAP. The green algae coefficient of variation $(C V)$ varied from 0 to 1.5 in the HRAP and WHP, but was constant at 0.9 to the $10^{\text {th }}$ week in MP1 and around 0.5 during all the experimental period for MP2. For the chlorophyll a, this coefficient varied in all the ponds.
\end{abstract}

Keywords: Ecologic index, Piggery waste, Plankton biomass, Ponds treatment

\section{INTRODUCTION}

The presence of the microorganisms is primordial in the biological wastewater treatment systems. As the organic matter is degraded, there is a natural succession of the microorganism, such as bacteria, algae, protozoa and rotifers that are fundamental links in this kind of system.

Micro-algae are an important part of wastewater treatment when the waste stabilization ponds are employed. Several factors, such as light intensity, ammonia and sulphide toxicity and, mainly, the surface organic loading applied to the pond are reported to pose some effect on the development of algae population in the ponds (Athayde et al. 2000). They are the microorganisms responsible for the molecular oxygen production, a vital element to the bacteria that participate in the biochemical oxidation of the organic matter. The presence of the algae in adequate levels assures the aerobic conditions in the pond. When the ecological balance is lost, there is a risk of anaerobic conditions, bringing as consequence the reduction of the system efficiency (Suetmasu, 1995). Another supplemental role of the algae in the ponds is the removal of nutrients, such as

Author for correspondence 
nitrogen, phosphorus and carbon (inorganic carbon - $\mathrm{CO}_{2}$ or bicarbonate) to satisfy their nutritive needs. Few species of the algae can survive in the water with elevated nutritive element concentration. The natural selection is made in benefit of some resistant species that are generally found in the polluted water. According to König (2000), the algae found in the stabilization ponds, in general, belong to Cyanobacteria (blue-green algae), Chlorophyta (green algae), Euglenophyta (pigmented flagellate or phytoflagellated) and Bacillariophyta (diatoms) phylum. In this kind of environment, they are not always present during the whole year and can vary with the organic load to the reactor, season, climate, latitude and wastewater quality. The residence time in the pond must be higher than the algae reproduction time (>1.6 days), otherwise they would be removed with the effluent without enough time for the reproduction (König, 2000).

The zooplankton represents the main agent of suspended solids reduction that results in the treatment. They are distributed in four groups in the stabilization ponds: ciliate, rotifers, copepoda and cladocera. Occasionally, there are free life amoeba, ostracoda, mite, nematodes and grubs of insect (Suetmasu, 1995).

Piggery waste is composed of animal's liquid and solid excrements with the water utilized to clean the installations. It has high level of biodegradable organic matter (around 55\%) and high number of contaminant elements, such as pathogenic material, nitrogen and minerals, such as copper, zinc and arsenic (Estrada and Hernández, 2002). Costa et al. (2000) observed mean values of total solids around 20,000 mg/L and COD of 30,000 $\mathrm{mg} / \mathrm{L}$ to piggery waste in Santa Catarina, Brazil. Zanotelli et al. (2002) observed 13 genera and 10 algae species of plankton biomass in the facultative ponds with piggery waste; the green algae being the genus with highest specific richness, while the Chlorella vulgaris was the most abundant species. Sevrin-Reyssac et al. (1995) observed that the algae proliferated in the water receiving piggery waste, mostly, belonging to green algae group (Chlorella sp, Scenedesmus $s p$, Oocystis sp, Chlamydomonas sp, Ankistrodesmus sp).

This paper reports a study aiming at analyzing the plankton biomass found in high rate algae pond, maturation ponds and water hyacinth pond, in series operation, applied to piggery waste treatment.

\section{MATERIALS AND METHODS}

The treatment system was composed of an equalizer, a settling tank, two anaerobic ponds (AP1 and AP2), a high rate algal pond (HRAP), two maturation ponds (MP1 and MP2) (System A) and a water hyacinth pond (WHP) (System B) (Fig. 1). The effluent went to the pond series up to the MP1, with a daily flow rate of $600 \mathrm{~L} / \mathrm{d}$, considering that part of it $(200 \mathrm{~L} / \mathrm{d})$ was sent to MP2 and the rest flowed to WHP $(400 \mathrm{~L} / \mathrm{d})$. The experiment was performed at the Experimental Unit of Piggery Waste Treatment of the Brazilian Company for Agricultural Research - EMBRAPA, Pig and Poultry, situated in Concórdia, SC, south of Brazil (Latitude: 27¹8'47", Longitude:

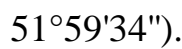

In this work only the secondary ponds were studied: HRAP, MP1, MP2 and WHP. Pond dimensions and operational conditions are presented in Table 1.

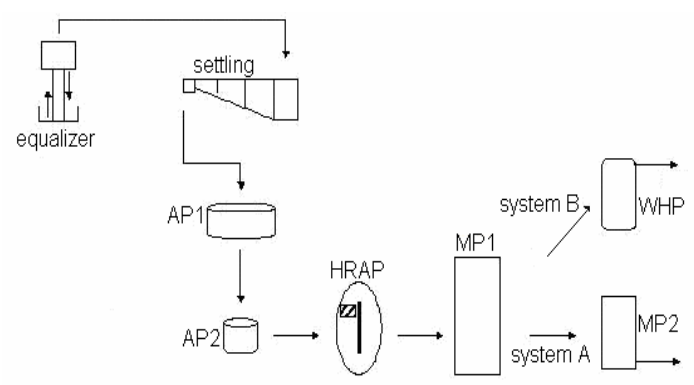

Figure 1 - Schematic diagram of the pilot ponds system. 
Table 1 - Pond dimensions and operational conditions.

\begin{tabular}{lcccccc}
\hline Pond & $\begin{array}{c}\text { Depth } \\
(\mathbf{m})\end{array}$ & $\begin{array}{c}\text { Area } \\
\left(\mathbf{m}^{2}\right)\end{array}$ & $\begin{array}{c}\text { Volume } \\
\left(\mathbf{m}^{\mathbf{3}}\right)\end{array}$ & $\begin{array}{c}\text { Flow rate } \\
\left(\mathbf{m}^{\mathbf{2}} / \mathbf{d}\right)\end{array}$ & $\begin{array}{c}\text { HRT } \\
(\mathbf{d a y s})\end{array}$ & $\begin{array}{c}\text { Surface loading rate } \\
(\text { KgCODs/ha.d })\end{array}$ \\
\hline HRAP & 0.50 & 12 & 6.3 & 0.60 & 10.5 & 357 \\
MP1 & 0.70 & 60 & 42 & 0.60 & 70 & 32 \\
MP2 & 0.70 & 6 & 3.44 & 0.20 & 17.2 & 90 \\
WHP & 0.70 & 6 & 3.44 & 0.40 & 8.6 & 148 \\
\hline
\end{tabular}

The ponds monitoring (HRAP, MP1, MP2, WHP) included: $\mathrm{pH}$, dissolved oxygen (DO), water temperature, total Kjeldahl nitrogen (TKN), nitrate $\left(\mathrm{NO}_{3}-\mathrm{N}\right)$, nitrite $\left(\mathrm{NO}_{2}-\mathrm{N}\right)$, total suspended solids (TSS), total phosphorus (TP), ammonia $\left(\mathrm{NH}_{4}-\mathrm{N}\right)$, soluble chemical oxygen demand (CODs), according to Standard Methods handbook (APHA, AWWA, WEF, 1998). The climatic data (wind speed, humidity, air temperature, solar radiation, rainfall) were provided by the Agricultural Research Company and Extension Rural of Santa Catarina (EPAGRI).

The sample collected for the phytoplankton and zooplankton analysis $(250 \mathrm{~mL}$ ) (total density) in the HRAP, MP1, MP2, WHP, was fixed with Lugol. The microorganism's identification, at a genus level, was done using a Neubauer chamber and Olympus BX 40 microscope, with 40 and 100 times amplification, coupled with an image analyzer system (Image Pro-Plus). The algal biomass was expressed as chlorophyll $a$. Other pigments were determined (phaeopigment and bacteriochlorophyll) according to Takahashi and Ishimura (1968, 1970). The chlorophyll $a$ determination was carried out according to Nusch (1980). The samples were collected in the inlet and outlet of each pond, in the morning (at 9:00 a.m.), at three depths: surface $(0.10 \mathrm{~m})$, middle $(0.25 \mathrm{~m})$ and bottom $(0.48 \mathrm{~m})$. The monitoring period was 32 weeks (February to October, 2003). The samples were collected weekly until the $20^{\text {th }}$ week and fortnightly in the weeks $21^{\text {th }}$ to $32^{\text {th }}$. Some samples were broken and damaged.

The biomass was also studied following the ecologic index described:

a)Relative density and specific richness

The species relative density (RD) is the individual number of the genus in the sample $(\mathrm{Na})$ in relation to the individual total number $(\mathrm{N})$, calculated by equation 1 (Odum, 1983):

$\mathrm{RD}=\mathrm{Na} / \mathrm{N} * 100 \%$
Where:

$\mathrm{RD}=$ relative density;

$\mathrm{Na}=$ individual number of the genus in the sample;

$\mathrm{N}=$ individual total number.

The population specific richness $(S)$ is the number of taxonomy units presented in every sample.

b) Jaccard index

The Jaccard index is frequently used to show the cenotyc affinity degree between two samples. This index considers the genus presence or absence without considering the microorganism's quantity. It was calculated by equation 2 (Margalef, 1983):

$\mathrm{C}=\{\mathrm{Sab} /(\mathrm{Sa}+\mathrm{Sb})-\mathrm{Sab}\} * 100 \%$

Where:

$\mathrm{Sa}=$ specific richness of sample $\mathrm{a}$;

$\mathrm{Sb}=$ specific richness of sample $\mathrm{b}$;

$\mathrm{Sab}=$ common numbers in two samples.

c) Specific occurrence index

The application of this index and the relative density established a species hierarchy in function of their importance in the samples. The species frequency $(\mathrm{F})$ in the samples of each pond was calculated according to equation 3 (Zulkifli, 1992):

$\mathrm{SOI}=\mathrm{Pi} / \mathrm{P} * 100 \%$ (3)

Where:

SOI = specific occurrence index;

$\mathrm{Pi}=$ frequency number of the species in the samples;

$\mathrm{P}=$ total number of samples.

The phytoplankton species were separated in the groups according to their frequency:

-absent species: not present in the samples;

-rare species: present in less than $25 \%$ of the samples;

-low frequency species: present between 26 and $50 \%$ of the samples;

-frequent species: present between 51 and $90 \%$ of the samples; 
-permanent species: present in more than $90 \%$ of the samples.

This index complemented any information of the specific richness, indicating the temporal capacity of the reception of every pond according to the presence of different species.

d)Productivity of algal biomass

The productivity of algal biomass (Pr) was calculated following equation 4 developed by Oswald (1988):

$\operatorname{Pr}=\mathrm{d}^{*} \mathrm{C} / \varnothing$

Where:

$\operatorname{Pr}=$ productivity of algal biomass $\left(\mathrm{g} / \mathrm{m}^{2} / \mathrm{d}\right)$;

$\mathrm{d}=$ pond depth $(\mathrm{m})$;

$\mathrm{C}=$ algal concentration, measured by TSS $(\mathrm{mg} / \mathrm{L})$;

$\varnothing=$ residence time (days).

e)Coefficient of variation (CV)

The coefficient of variation (CV) was determined for the chlorophyll $a$ and for the phytoplankton (green algae) according to equation 5 (Håkanson et al., 2003):

$\mathrm{CV}=$ standard deviation/average

(5)
The $\mathrm{CV}$-values regulated the theoretically the highest predictive power of the models and the reliability of data used for model validations.

\section{RESULTS AND DISCUSSION}

\section{Climatic parameters}

The mean air temperature was around 13 and $24^{\circ} \mathrm{C}$ along the experimental period. The mean rainfall was around 47 and $235 \mathrm{~mm}$; it was above $200 \mathrm{~mm}$ in February and October and above $100 \mathrm{~mm}$ in April and June. In the other months, the rainfall was lower than $100 \mathrm{~mm}$. The wind speed varied from 0 and $1.9 \mathrm{~m} / \mathrm{s}$. The higher means of air humidity occurred in June $(83.5 \%)$ and August $(80.6 \%)$. February, June, July and September were the months with lowest insolation; during the other experimental period months the insolation was higher than $200 \mathrm{hh}: \mathrm{mm}$. Solar radiation varied from 45 to $111 \mathrm{cal} / \mathrm{cm}^{2} /$ day and in February, March, April and October, the highest values were found. The average values for the climatic data, along the monitoring period for every pond, are presented in Table 2.

Table 2 - Average values for climatic data (February-October/2003).

\begin{tabular}{lcccccc}
\hline & $\begin{array}{c}\text { Solar radiation } \\
\left(\mathbf{c a l} / \mathbf{c m}^{2} / \mathbf{d a y}\right)\end{array}$ & $\begin{array}{c}\text { Wind speed } \\
(\mathbf{m} / \mathbf{s})\end{array}$ & $\begin{array}{c}\text { Rainfall } \\
(\mathbf{m m})\end{array}$ & $\begin{array}{c}\text { Humidity } \\
(\mathbf{\%})\end{array}$ & $\begin{array}{c}\mathbf{T}^{\mathbf{0}} \mathbf{C} \\
(\mathbf{a i r})\end{array}$ & $\begin{array}{c}\text { Insolation } \\
(\mathbf{h h}: \mathbf{m m})\end{array}$ \\
\hline February & 111 & 1.7 & 221 & 77.5 & 23.7 & $166: 30$ \\
March & 109 & 1.6 & 96 & 78.2 & 22.0 & $213: 10$ \\
April & 91 & 1.7 & 114 & 78.6 & 18.5 & $206: 50$ \\
May & 71 & 1.6 & 70 & 76.5 & 14.6 & $205: 55$ \\
June & 45 & 1.3 & 102 & 83.5 & 15.9 & $120: 05$ \\
July & 47 & 1.6 & 74 & 77.7 & 15.1 & $153: 05$ \\
August & 76 & 1.6 & 47 & 80.6 & 13.2 & $220: 15$ \\
September & 88 & 0.0 & 55 & 79.8 & 17.4 & $197: 40$ \\
October & 109 & 1.9 & 235 & 71.4 & 20.7 & $231: 05$ \\
\hline
\end{tabular}

\section{Physicochemical parameters}

The average water temperature remained around $17^{\circ} \mathrm{C}$ during the period of the study. The ponds were well aerated by the algae photosynthetic activity and the DO varied from $1.88 \mathrm{mg} / \mathrm{L}$ in WHP to $5.45 \mathrm{mg} / \mathrm{L}$ in MP1. Minimum $\mathrm{pH}$ value was 7.61 in WHP and varied from 8.57 to 9.0 for the other ponds. These results were similar to those obtained by Costa et al. (2002) in a high rate pond and maturation pond series system. Ammonia reduced in the treatment system and its average concentration was smaller in the outlet of
System A $(19 \mathrm{mg} / \mathrm{L})$ than in the System B $(28$ $\mathrm{mg} / \mathrm{L})$. The TKN concentration was higher in the System B $(51 \mathrm{mg} / \mathrm{L})$ than in the System A (34 $\mathrm{mg} / \mathrm{L}$ ). The nitrites concentration was high in the HRAP effluent and decreased along the treatment system. The nitrates followed the same trend in the HRAP effluent $(373 \mathrm{mg} / \mathrm{L})$. The nitrite and nitrate increased in the HRAP, due to a nitrification. Phosphorus reduced along the system with similar concentrations in MP2 effluent and WHP effluent (Systems A and B) (around $6 \mathrm{mg} / \mathrm{L}$ ). These nutrients were assimilated by the phytoplankton in 
the ponds series, with removal efficiency over $90 \%$ of nitrite and around $75-80 \%$ of nitrate.

The averages of the TSS $(245 \mathrm{mg} / \mathrm{L})$ and CODs $(713 \mathrm{mg} / \mathrm{L})$ were elevated in the HRAP, probably due to the high mean concentration of algae, and the concentration of these parameters at the end of System A was a little higher than in System B. The mean of the removal efficiency to Systems A and $\mathrm{B}$ was higher than $95 \%$ in the analyzed parameters, except for the TSS, nitrite and nitrate.
In this work, the organic loading rate $(357 \mathrm{~kg}$ COD soluble/ha.d to HRAP, see Table 1) was higher than that applied by Oliveira (2002) (187 $\mathrm{kg}$ COD soluble/ha.d) to HRAP and lower than that applied by Zanotelli (2002) (470 kg COD total/ha.d) to a facultative pond with piggery waste.

Table 3 presents the mean results and standard deviations obtained by each pond during the monitoring period of the study.

Table 3 - Means results and standard deviation of the physicochemical measured variables $(\mathrm{n}=25)$.

\begin{tabular}{|c|c|c|c|c|c|c|c|}
\hline Parameter & $\begin{array}{c}\text { HRAP } \\
\text { influent }\end{array}$ & $\begin{array}{c}\text { HRAP } \\
\text { effluent }\end{array}$ & $\begin{array}{c}\text { MP1 } \\
\text { effluent }\end{array}$ & $\begin{array}{c}\text { MP2 } \\
\text { effluent } \\
\text { (System A) }\end{array}$ & $\begin{array}{c}\text { WHP } \\
\text { effluent } \\
\text { (System B) }\end{array}$ & $\begin{array}{c}\text { Removal } \\
\text { efficiency in } \\
\text { System A (\%) }\end{array}$ & $\begin{array}{c}\text { Removal } \\
\text { efficiency in } \\
\text { System B }(\%)\end{array}$ \\
\hline Temperature $\left({ }^{\circ} \mathrm{C}\right)$ & $16.6 \pm 3.6$ & $16.8 \pm 3.2$ & $17 \pm 3.3$ & $17 \pm 3.2$ & $17.3 \pm 3.1$ & - & - \\
\hline DO $(\mathrm{mg} / \mathrm{L})$ & $0.5 \pm 0.2$ & $3.1 \pm 1.7$ & $5.5 \pm 2.6$ & $4.1 \pm 1.7$ & $1.9 \pm 1.6$ & - & - \\
\hline $\mathrm{pH}$ & $7.0 \pm 0.5$ & $8.6 \pm 0.6$ & $9.0 \pm 0.7$ & $8.8 \pm 0.9$ & $7.6 \pm 0.6$ & - & - \\
\hline CODs $(\mathrm{mg} / \mathrm{L})$ & $622 \pm 351$ & $713 \pm 517$ & $322 \pm 172$ & $269 \pm 81$ & $222 \pm 100$ & 95 & 96 \\
\hline TSS (mg/L) & $252 \pm 135$ & $245 \pm 140$ & $84 \pm 35$ & $93 \pm 41$ & $83 \pm 65$ & 60 & 64 \\
\hline TKN (mg/L) & $776 \pm 272$ & $240 \pm 153$ & $53 \pm 32$ & $34 \pm 20$ & $51 \pm 64$ & 98 & 97 \\
\hline $\mathrm{NH}_{4}-\mathrm{N}(\mathrm{mg} / \mathrm{L})$ & $657 \pm 204$ & $209 \pm 86$ & $36 \pm 36$ & $19 \pm 23$ & $28 \pm 23$ & 98 & 97 \\
\hline $\mathrm{NO}_{2}-\mathrm{N}(\mathrm{mg} / \mathrm{L})$ & $0.6 \pm 0.8$ & $313 \pm 178$ & $75 \pm 67$ & $32 \pm 32$ & $23 \pm 40$ & 90 & 93 \\
\hline $\mathrm{NO}_{3}-\mathrm{N}(\mathrm{mg} / \mathrm{L})$ & $2.2 \pm 2.2$ & $373 \pm 427$ & $114 \pm 114$ & $63 \pm 84$ & $92 \pm 148$ & 83 & 75 \\
\hline $\mathrm{TP}(\mathrm{mg} / \mathrm{L})$ & $27.5 \pm 14$ & $23 \pm 12$ & $7 \pm 4$ & $6 \pm 4$ & $6.4 \pm 3.6$ & 97 & 97 \\
\hline
\end{tabular}

\section{Plankton}

Table 4 presents the mean, maximum and minimum values of the microorganisms total density found in the ponds. The WHP showed the lowest green algae concentration due to a lower DO (1.88 mg/L) and COD soluble (222 mg/L) concentrations. The main assimilation of carbon source by the algae was in the biodegradation of organic matter. In the other ponds, the green algae were in higher density on the surface, probably due to the presence of solar radiation light $(\sim 100$ $\mathrm{cal} / \mathrm{cm}^{2} /$ day). The diatoms preferred the bottom of the ponds. König (2000) reported that the factors controlling the displacement and the distribution of the algae in the water column were, mainly, the temperature and light intensity. When the samples were collected (9h00min), there was an increase in the light intensity, where algae movement occurred in the liquid mass.

The green algae increase was evident in the MP1 surface containing a high value of DO $(5.5 \mathrm{mg} / \mathrm{L})$ concentration and the HRAP with an increase of the soluble COD (622 to $713 \mathrm{mg} / \mathrm{L}$ ) concentration. The high quantity of protozoa (Paramecium $s p$ ) and metazoa in this experiment was present in WHP (Table 4).
The highest diatoms density was present in the bottom of MP2 and in lower density in the HRAP, which received a higher organic load, being the first pond of the study series to produce higher concentrations of nitrite, nitrate and TSS. Cyanobacteria occurred in different depths of MP2 with lower ammonia $(19 \mathrm{mg} / \mathrm{L})$ concentration. The cyanobacteria occurrence in minor quantity indicated lower effluent toxicity (Zanotelli, 2002). The protozoa total density present was conversely proportional to the density of the green algae in the HRAP and WHP. In the WHP, the hyacinth's shadow rendered the phytoplankton proliferation difficult, and the algae grazing occurrence through the zooplankton, caused lower algae density. The metazoa and phytofllagelated were only in the WHP. Maizonave et al. (2005) reported total densities of phytoplankton $\left(10^{3}\right.$ to $\left.10^{4} \mathrm{org} / \mathrm{mL}\right)$ in Lomba do Sabão Reservoir (RS, Brazil), with BOD5 of $391 \mathrm{mg} / \mathrm{L}$. Cruz et al. (2005) obtained values between 0 and $8 \times 10^{6} \mathrm{ind} / \mathrm{mL}$ in the stabilization ponds with the domestic sewage and COD of $400 \mathrm{mg} / \mathrm{L}$. Zanotelli (2002) worked with piggery waste and obtained total density of $10^{11}$ ind $/ \mathrm{mL}$. 
Table 4 - Mean, minimum and maximum microorganisms total density (x 10 $\left.0^{4} \mathrm{ind} / \mathrm{mL}\right)$ found in the ponds $(\mathrm{n}=25)$.

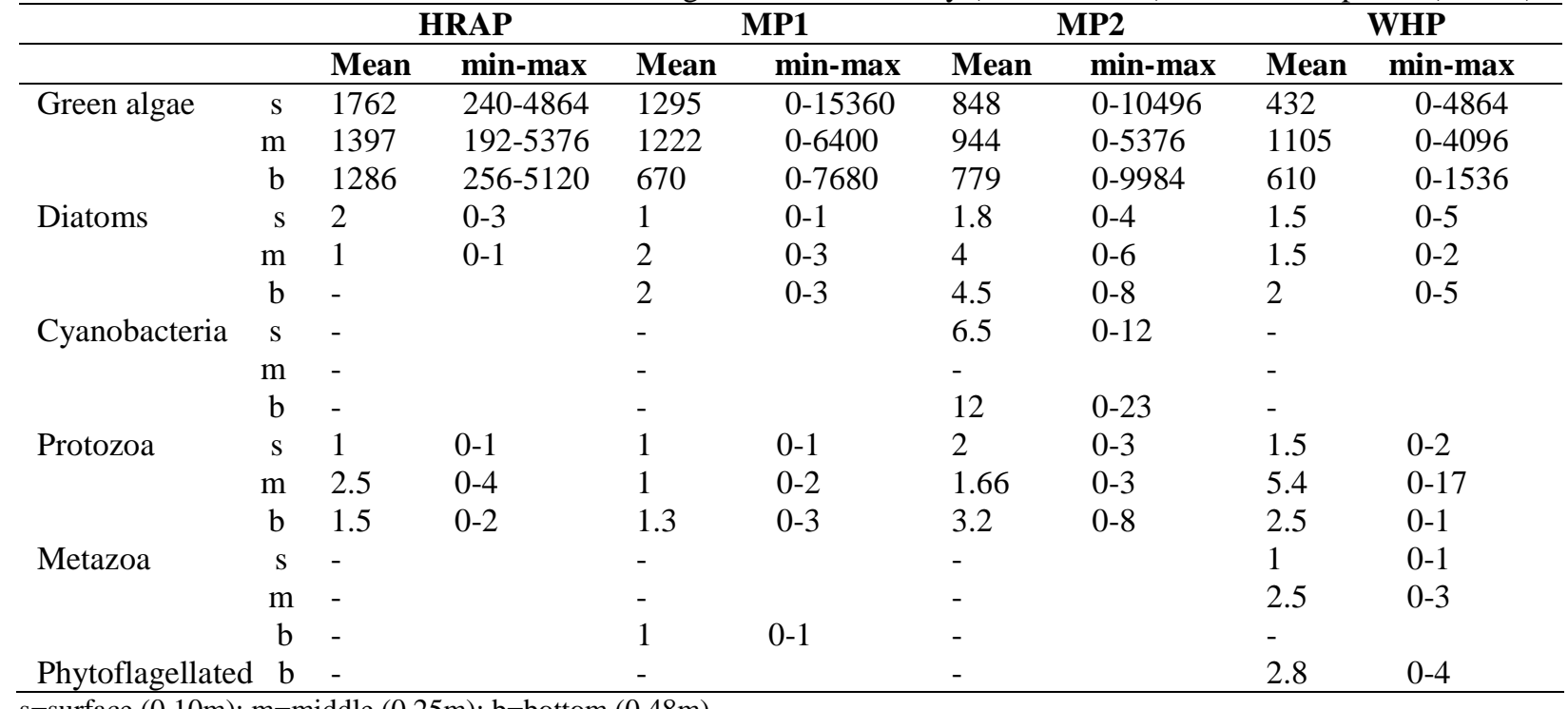

$\mathrm{s}=$ surface $(0.10 \mathrm{~m}) ; \mathrm{m}=$ middle $(0.25 \mathrm{~m})$; $\mathrm{b}=\operatorname{bottom}(0.48 \mathrm{~m})$

\section{Pigments}

Figure 2 shows the average value of the chlorophylled and no-chlorophylled species present in the ponds with predominance of Chlorella sp. The relative density of the green algae (chlorophylled species) decreased as the effluent passed in the pond systems. In the HRAP, this density was $99.8 \%$ and in the maturation ponds, it was higher than $98.4 \%$. In the WHP, the green algae density was $97.4 \%$, the zooplankton (no-chlorophylled species) contributed with $2.1 \%$, it presented higher density in this pond.

The HRAP had the highest total density $\left(1,486 \times 10^{4} \mathrm{ind} / \mathrm{mL}\right)$ and the WHP the lowest density $\left(443 \times 10^{4} \mathrm{ind} / \mathrm{mL}\right)$ (chlorophylled species). The protozoa and diatoms were present in only $0.2 \%$ of the HRAP and $0.3 \%$ of the maturation ponds.

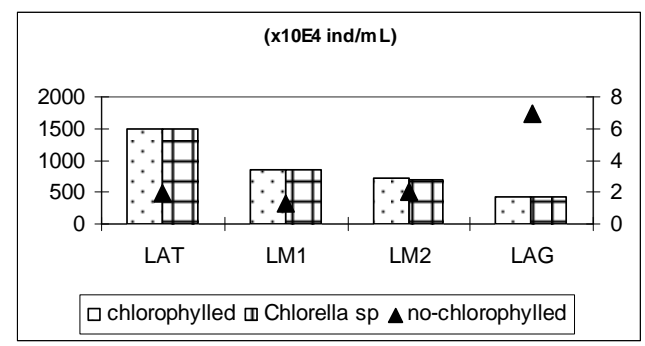

Figure 2 - Total chlorophylled (left axis) and no-chlorophylled (right axis) species and Chlorella sp (x 10 $\mathrm{ind} / \mathrm{mL})$ (left axis).

Table 5 shows the mean results, minimum and maximum values of the chlorophyll $a$ (CHL-a), bacteriochlorophyll $(\mathrm{BCH})$ and phaeopigment in the ponds (HRAP, MP1, MP2, WHP) measured during the study research period. Table 5 showed that chlorophyll $a$ was higher in the HRAP $(>2,000 \mu \mathrm{g} / \mathrm{L})$ at all the depths and it coincided with the higher organic load $(357 \mathrm{~kg}$ COD soluble/ha.d), elevated solar radiation $(\sim 100$ $\mathrm{cal} / \mathrm{cm}^{2} /$ day $)$ and temperature $\left(17^{\circ} \mathrm{C}\right)$. The highest concentration was at the bottom of the HRAP and
MP1 and on the surface of MP2 and WHP, near the average values obtained by Oliveira (2002) with piggery waste $(2,608 \mu \mathrm{g} / \mathrm{L})$.During the day, some algae changed in the liquid mass and selected the depth where the light intensity was more adequate to photosynthesis (König, 2000).

Picot et al. (1992) obtained, in domestic effluents treated in HRAP, chlorophyll $a$ of $2,000 \mu \mathrm{g} / \mathrm{L}$, in the sunny and hot months in the Mediterranean region, with the same temperature $\left(17.2^{\circ} \mathrm{C}\right)$. 
Table 5 - Mean results, lowest and highest values of chlorophyll $a$ (CHL- $a$ ), bacteriochlorophyll (BCH) and phaeopigment $(\mathrm{n}=25)$.

\begin{tabular}{cccccccccc}
\hline \multirow{2}{*}{ Ponds } & & HRAP & HRAP & MP1 & MP1 & MP2 & MP2 & WHP & WHP \\
\cline { 2 - 9 } & & mean & min-max & mean & min-max & mean & min-max & mean & min-max \\
\hline CHL-a & $\mathrm{s}$ & 2021 & $47-7905$ & 1624 & $456-4241$ & 1740 & $214-4585$ & 1361 & $372-4371$ \\
$(\mu \mathrm{g} / \mathrm{L})$ & $\mathrm{m}$ & 2147 & $93-7756$ & 1746 & $28-3515$ & 1427 & $344-4036$ & 1193 & $37-4036$ \\
& $\mathrm{~b}$ & 2502 & $37-8082$ & 2122 & $502-4566$ & 1219 & $269-3171$ & 1355 & $19-4297$ \\
$\mathrm{BCH}$ & $\mathrm{s}$ & 979 & $17-1672$ & 917 & $25-2797$ & 959 & $17-2041$ & 867 & $15-2486$ \\
$(\mu \mathrm{g} / \mathrm{L})$ & $\mathrm{m}$ & 1019 & $17-2150$ & 1027 & $59-2654$ & 964 & $8-2058$ & 984 & $8-3108$ \\
& $\mathrm{~b}$ & 1121 & $17-2268$ & 897 & $185-1873$ & 901 & $18-2108$ & 978 & $67-1890$ \\
Phaeopigment & $\mathrm{s}$ & 282 & $208-930$ & 317 & $6-1687$ & 378 & $44-1330$ & 456 & $7-2259$ \\
$(\mu \mathrm{g} / \mathrm{L})$ & $\mathrm{m}$ & 482 & $132-5746$ & 188 & $67-712$ & 592 & $225-1632$ & 291 & $42-831$ \\
& $\mathrm{~b}$ & 184 & $26-1666$ & 715 & $87-3511$ & 279 & $268-725$ & 275 & $18-977$ \\
\hline
\end{tabular}

$\mathrm{s}=$ surface $(0.10 \mathrm{~m}) ; \mathrm{m}=$ middle $(0.25 \mathrm{~m}) ; \mathrm{b}=$ bottom $(0.48 \mathrm{~m})$.

Bassères (1990) obtained chlorophyll $a$ of 2,855 $\mu \mathrm{g} / \mathrm{L}$, with piggery waste treated in the HRAP (COD soluble of $1,351 \mathrm{mg} / \mathrm{L}$ ). Zanotelli et al. (2002) concluded that the chlorophyll $a$ concentration was lower in the aerated facultative pond than in the facultative pond without aeration; and the species diversity was higher in the aerated pond, treating piggery waste in the climatic conditions of Santa Catarina (Brazil).

In the HRAP, the high chlorophyll $a$ concentration $(>2,000 \mu \mathrm{g} / \mathrm{L})$ coincided as expected with the elevated TSS (245 $\mathrm{mg} / \mathrm{L})$ and soluble COD concentration (713 mg/L). Bacteriochlorophyll was lower than chlorophyll $a$, with similar concentrations (around 1,000 $\mu \mathrm{g} / \mathrm{L}$ ) in the several ponds and showed that the bacteria were present in the organic matter degradation of the effluent. The higher values of the standard deviation in the pigmented concentrations were probably due to the transportation and storage of the samples. The phaeopigments were the degraded products of chlorophyll $a$. The period between the collection and analysis of the pigments was up to thirty days. Zulkifli (1992) used two high rate algal ponds (A and B) with domestic effluent (COD of 318 and $294 \mathrm{mg} / \mathrm{L}$, respectively) and obtained bacteriochlorophyll concentration of 230 and 470 $\mu \mathrm{g} / \mathrm{L}$ for the pond $\mathrm{A}$ and $\mathrm{B}$, respectively. The phaeopigment had lower concentration $(<715$ $\mu \mathrm{g} / \mathrm{L})$, proving that there was little chlorophyll $a$ degradation in the samples.

\section{Ecologic index}

Figure 3 shows the temporal variation of the specific richness number in the ponds. The WHP presented the most diversity (10 species), followed by MP2 (9 species), HRAP (6 species) and MP1 (5 species). The lowest specific richness observed in the HRAP was associated with the mono-specific population, especially Chlorella $s p$. The results obtained by Zulkifli (1992) showed the specific richness situated between 3 and 15 species for the HRAP, with domestic effluent (COD of $373 \mathrm{mg} / \mathrm{L}$, residence time of 8 days). The highest number of species occurred between the $6^{\text {th }}$ and $10^{\text {th }}$ weeks of the monitoring period, corresponding to period of highest solar radiation $\left(\sim 100 \mathrm{cal} / \mathrm{cm}^{2} /\right.$ day $)$

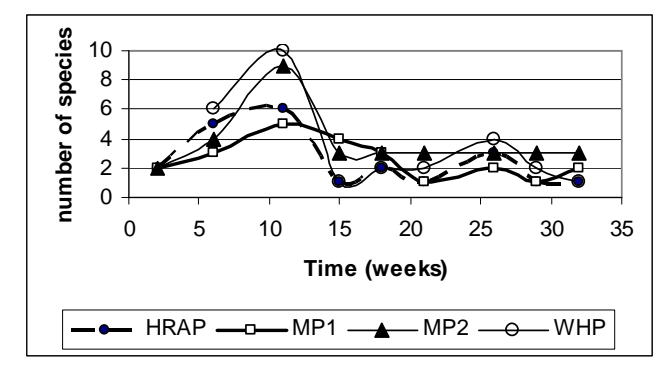

Figure 3 - Specific richness of the plankton population in several ponds during monitoring period (32 weeks). 
Figure 4 shows the change of Jaccard index calculated for the Systems A and B (HRAP influent to MP2 or WHP effluent). The index of $100 \%$ corresponded to a complete similitude of two populations (the same number of species and the same species presence). In both the systems, the index of $100 \%$ occurred when Chlorella $s p$ and diatoms were observed in the influent and in the effluent systems. The Jaccard index was higher in the System B during the weeks of lowest solar radiation ( $\sim 50 \mathrm{cal} / \mathrm{cm}^{2} /$ day $)$. Zulkifli (1992) obtained this index lower than $40 \%$ to primary and secondary ponds, but in the high rate algal ponds, this index had an average of $60 \%$ (from 20 to $100 \%)$.

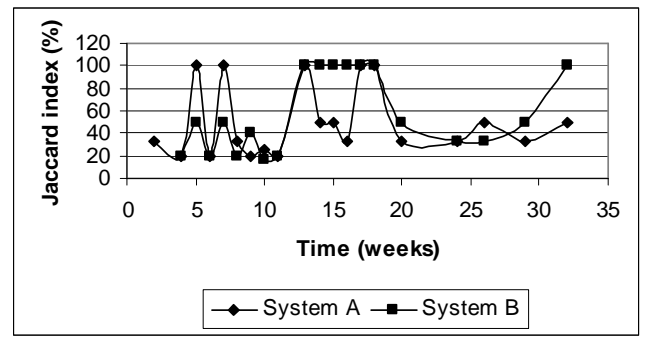

Figure 4 - Change of Jaccard index in Systems A and B during the monitoring period (32 weeks).

Table 6 - Specific Occurrence Index (SOI) and their category for the identified species to several ponds.

\begin{tabular}{|c|c|c|c|c|c|c|c|c|}
\hline \multirow{2}{*}{ Taxon } & \multicolumn{2}{|l|}{ SOI } & \multicolumn{6}{|c|}{ Category } \\
\hline & HRAP & MP1 & MP2 & WHP & HRAP & MP1 & MP2 & WHP \\
\hline Nitzschia $s p^{*}$ & 0.05 & 0.1 & 0.11 & 0.17 & $\mathrm{R}$ & $\mathrm{R}$ & $\mathrm{R}$ & $\mathrm{R}$ \\
\hline Chlorella $s p^{*}$ & 1 & 1 & 1 & 1 & $P$ & $\mathrm{P}$ & $\mathrm{P}$ & $P$ \\
\hline Vorticella $s p^{* *}$ & 0.01 & 0.01 & 0.01 & 0.03 & $\mathrm{R}$ & $\mathrm{R}$ & $\mathrm{R}$ & $\mathrm{R}$ \\
\hline Diatoms* & 0.01 & 0.08 & 0.05 & 0.01 & $\mathrm{R}$ & $\mathrm{R}$ & $\mathrm{R}$ & $\mathrm{R}$ \\
\hline Paramecium $s p^{* *}$ & 0.05 & 0 & 0.06 & 0.03 & $\mathrm{R}$ & $\mathrm{a}$ & $\mathrm{R}$ & $\mathrm{R}$ \\
\hline Amphiletus sp ${ }^{* *}$ & 0.01 & 0 & 0.05 & 0.03 & $\mathrm{R}$ & $\mathrm{a}$ & $\mathrm{R}$ & $\mathrm{R}$ \\
\hline Aspidisca $s p^{* *}$ & 0.03 & 0.1 & 0.05 & 0.01 & $\mathrm{R}$ & $\mathrm{R}$ & $\mathrm{R}$ & $\mathrm{R}$ \\
\hline Centropyxis sp ${ }^{* *}$ & 0.01 & 0 & 0 & 0 & $\mathrm{R}$ & $\mathrm{a}$ & $\mathrm{a}$ & $\mathrm{a}$ \\
\hline Scenedesmus $s p^{*}$ & 0 & 0.05 & 0.08 & 0.01 & $\mathrm{a}$ & $\mathrm{R}$ & $\mathrm{R}$ & $\mathrm{R}$ \\
\hline Philodina $s p^{* *}$ & 0 & 0.01 & 0 & 0 & $\mathrm{a}$ & $\mathrm{R}$ & $\mathrm{a}$ & $\mathrm{a}$ \\
\hline Planktothrix $s p^{*}$ & 0 & 0 & 0.03 & 0 & $\mathrm{a}$ & $\mathrm{a}$ & $\mathrm{R}$ & $\mathrm{a}$ \\
\hline Anabaena $s p^{*}$ & 0 & 0 & 0.05 & 0 & $\mathrm{a}$ & $\mathrm{a}$ & $\mathrm{R}$ & $\mathrm{a}$ \\
\hline Tokophrya sp ${ }^{* *}$ & 0 & 0 & 0.01 & 0 & $\mathrm{a}$ & $\mathrm{a}$ & $\mathrm{R}$ & $\mathrm{a}$ \\
\hline Euglena $s p * *$ & 0 & 0 & 0 & 0.01 & $\mathrm{a}$ & $\mathrm{a}$ & $\mathrm{a}$ & $\mathrm{R}$ \\
\hline Nematode $* *$ & 0 & 0 & 0 & 0.01 & $\mathrm{a}$ & $\mathrm{a}$ & $\mathrm{a}$ & $\mathrm{R}$ \\
\hline Brachionus sp ${ }^{* *}$ & 0 & 0 & 0 & 0.03 & $\mathrm{a}$ & $\mathrm{a}$ & $\mathrm{a}$ & $\mathrm{R}$ \\
\hline Amoeba $s p^{* *}$ & 0 & 0 & 0 & 0.03 & $\mathrm{a}$ & $\mathrm{a}$ & $\mathrm{a}$ & $\mathrm{R}$ \\
\hline Lepocinclis $s p^{* *}$ & 0 & 0 & 0 & 0.03 & $\mathrm{a}$ & $\mathrm{a}$ & $\mathrm{a}$ & $\mathrm{R}$ \\
\hline
\end{tabular}

$\mathrm{P}=$ permanent $(>90 \%) ; \mathrm{R}=\operatorname{rare}(<25 \%) ; \mathrm{a}=$ absent $(0 \%)$.

*phytoplankton; **zooplankton 
Table 6 and Figure 5 show the distribution of the specific occurrence index (SOI) of the plankton species and their category in the pond.

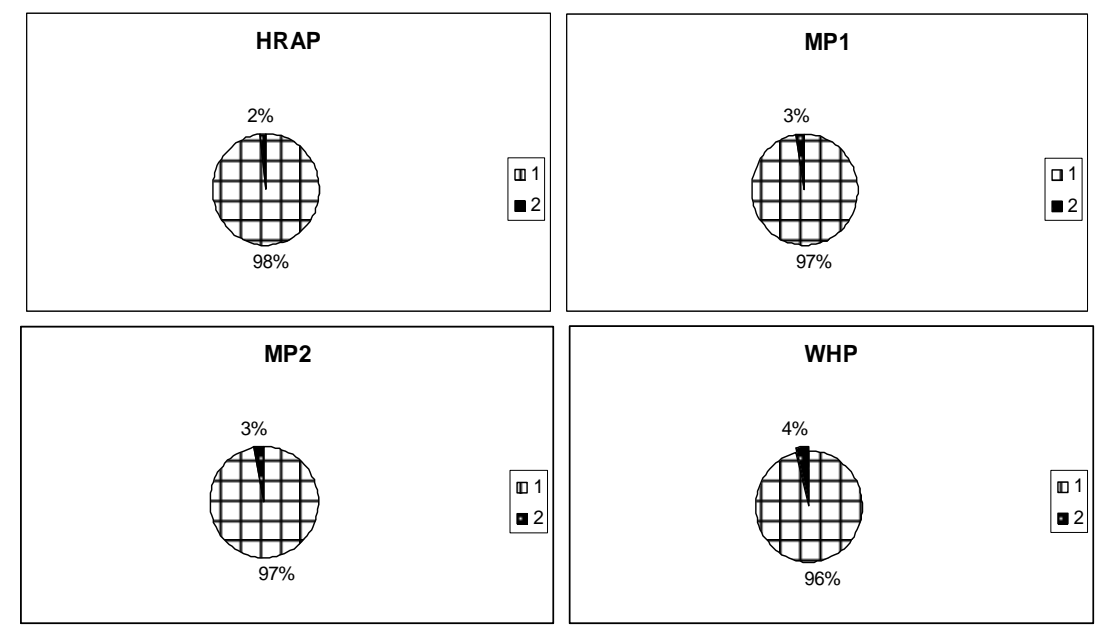

1=permanent species $(>90 \%) ; 2=$ rare species $(<25 \%)$.

Figure 5 - Distribution of the Specific Occurrence Index (SOI) of the plankton species in the ponds.

The specific occurrence index (SOI) for the groups or species found in the ponds, was classified in the following groups: permanent species ( $>90 \%)$, rare species $(<25 \%)$. Frequent species $(51-90 \%)$ and low frequency species $(26-50 \%)$ were not found in the ponds during the monitoring period. Chlorella $s p$ was present in all the samples, with high density, being a permanent species. This species developed an important and regular quantity along the study period. The frequent species were: Nitzschia $s p$, Vorticella $s p$, diatoms and Aspidisca sp. The rare species were, in the HRAP: Paramecium sp, Amphileptus sp, Centropyxis sp, Nitzschia sp, Vorticella $s p$, diatoms and Aspidisca sp; in MP1: Scenedesmus $s p$, Philodina sp, Nitzschia $s p$, Vorticella $s p$, diatoms and Aspidisca sp; in MP2: Paramecium sp, Amphileptus sp, Scenedesmus sp, Plantothrix $s p$, Anabaena sp, Tokophrya sp, Nitzschia sp, Vorticella $s p$, diatoms and Aspidisca $s p$; in WHP: Nitzschia sp, Vorticella sp, diatoms, Aspidisca sp, Paramecium sp, Amphileptus sp, Scenedesmus sp, Euglena sp, Lepocinclis sp, Amoeba sp, Brachionus $s p$ and a nematode. The dominant algae found were chlorophyceae. Cromar and Fallowfield (2003) reported this dominance in the wastewater treated in the HRAP during the summer season in Scotland.

Figure 6 shows the temporal variation of productivity $\left(\mathrm{gTSS} / \mathrm{m}^{2} /\right.$ day) in the ponds. The average productivity of algal biomass was 10 $\mathrm{gTSS} / \mathrm{m}^{2} / \mathrm{d}$ to HRAP and it didn't reach this value in the two maturation ponds, being lower than 1.5 $\mathrm{gTSS} / \mathrm{m}^{2} / \mathrm{d}$ to MP1. In the WHP, the productivity presented a large variation along the experimental period, with an average of $8 \mathrm{gTSS} / \mathrm{m}^{2} / \mathrm{d}$. The lower productivity in MP1 could be due to the long residence time (70 days). The seasonal variation in the first weeks of the experimental period was evident because of the higher solar radiation and temperature. Zulkifli (1992) concluded that the residence time was the predominant variable to the algal productivity, the long residence time presenting the lowest productivity of algal biomass. Garcia et al. (2002) obtained algal productivity of $12.7 \mathrm{gTSS} / \mathrm{m}^{2} / \mathrm{d}$ to pond A and $14.8 \mathrm{gTSS} / \mathrm{m}^{2} / \mathrm{d}$ to pond $\mathrm{B}$, both high rate algal ponds, with domestic effluent (COD total 170 $\mathrm{mg} / \mathrm{L}$ ) and this last pond presented higher productivity in relation to the short residence time (3 days). 

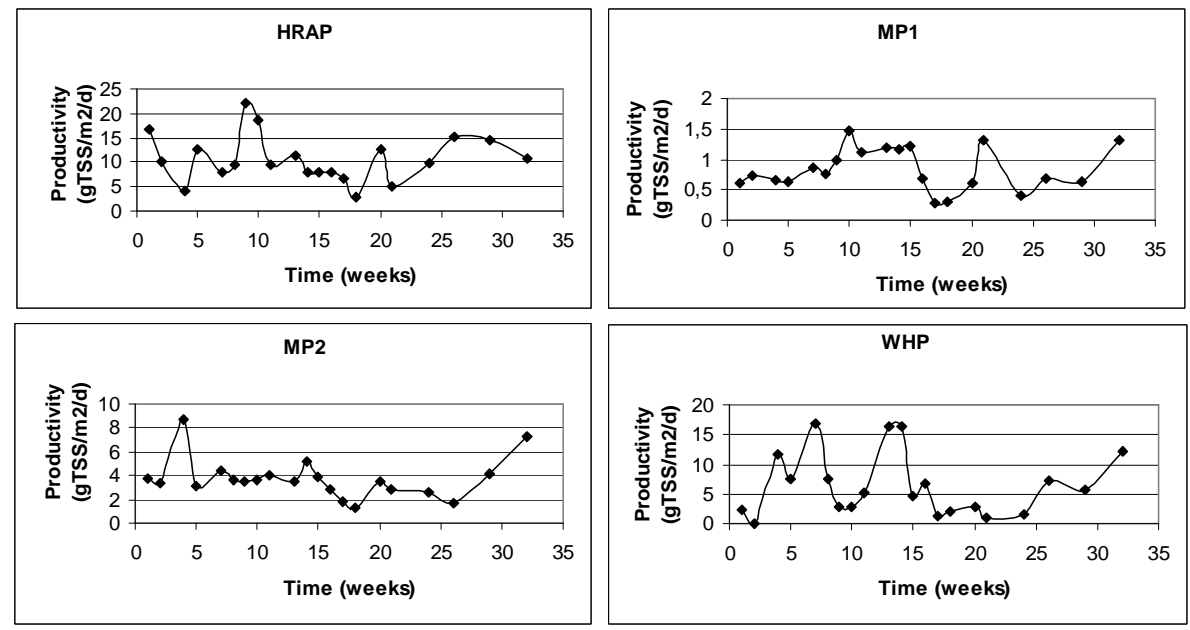

Figure 6 - Temporal variation of the algal productivity $\left(\mathrm{gTSS} / \mathrm{m}^{2} / \mathrm{d}\right)$ in several ponds.

The coefficient of variation, $\mathrm{CV}$-values, regulates the theoretically highest predictive power of models and the reliability of data used for the model validations. The CV-value is often referred to as the relative standard deviation and by using this concept, one can directly compare the uncertainties of different variables given in different dimensions (Håkanson et al. 2003).

Figure 7 shows the coefficient of variation $(\mathrm{CV})$ values calculated for chlorophyll $a$ and green algae in the ponds during 32 weeks. The CV average values for the green algae for the HRAP, MP1,
MP2 and WHP were: $0.60 ; 0.72 ; 0.58 ; 0.69$, respectively.

The green algae CV presented a good stability in the MP1 (until 10th day) and MP2. In MP1 and WHP, the values were $>1$ and a high variability in the chlorophyll a concentration was observed. Håkanson et al. (2003) obtained, in Danube River, $\mathrm{CV}$ between 0.5 and 1 for chlorophyll $a$ and green algae. Similar coefficients were obtained in this study for chlorophyll $a$ and green algae: CV between 0 and 1 for the HRAP and MP2 and CV between 0 and 1.5 for the MP1 and WHP.
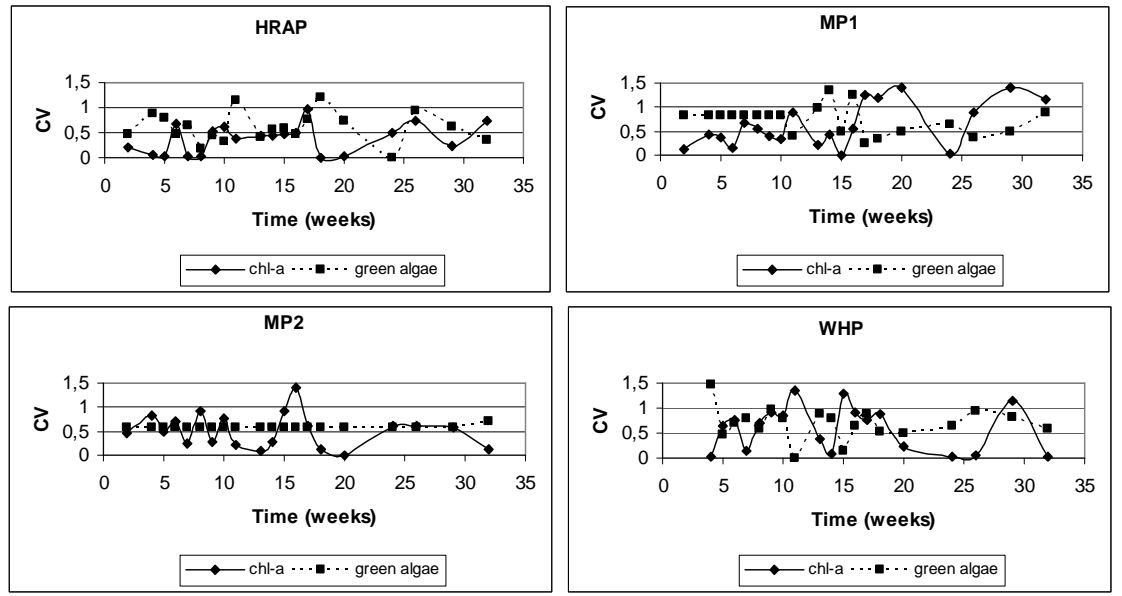

Figure 7 - CV values for chl- $a$ and green algae to several ponds along to the time (weeks). 


\section{CONCLUSION}

The piggery waste treatment system presented good efficiency in the removal of the organic matter (COD) and the nutrients (ammonia, nitrogen, nitrite, nitrate and phosphorus). Low organic matter concentration was obtained in all ponds, due to the adequate environmental conditions for the algae development and the assimilation of the nutrients. The algae removed the nutrients, such as nitrogenous compounds and phosphorus. In the light of the results presented here, it could be concluded that in the conditions studied, the Chorella $s p$ was the dominant species along the experiment. The green algae predominated, in relation to other organisms, in all the ponds. The protozoa density was conversely proportional to the density of the green algae in the HRAP (that presented higher COD soluble, nitrates, nitrites and TSS concentrations) and WHP (with lower COD soluble and DO concentrations). The highest species diversity occurred in the MP2 and WHP ponds that had lower nutrient (nitrogen compounds and total phosphorus) concentrations. The chlorophyll $a$ concentration and the productivity of algal biomass were elevated in the high rate algal pond that received the high organic load. The low specific richness was associated with the mono-specific population of Chlorella sp. The specific occurrence index was similar in the HRAP and MP1 and between MP2 and WHP. The coefficient of variation (CV) for the green algae remained constant until the 10th week for the MP1 and along the experimental period for the MP2. The CV for chlorophyll $a$ was very variable in all the ponds.

\section{RESUMO}

Este trabalho teve como objetivo estudar a biomassa do plâncton encontrado em um sistema de tratamento de dejetos suínos, formado por uma série de lagoas. Foram monitoradas 1 lagoa de alta taxa (LAT), 2 lagoas de maturação (LM1, LM2) (sistema A) e 1 lagoa de aguapés (LAG) (sistema B), durante 32 semanas, por meio de variáveis físico-químicas tais como $\mathrm{pH}$, temperatura, oxigênio dissolvido, demanda química de oxigênio, compostos nitrogenados e fósforo total. Igualmente, foram feitas identificações da biomassa planctônica, a nível de gênero, e calculados índices ecológicos que permitem descrever o seu desenvolvimento dentro das lagoas. O sistema de tratamento para dejetos suínos apresentou boa eficiência na remoção de matéria orgânica (DQOs) e nutrientes (nitrogênio, amônia, nitrato, nitrito e fósforo). Os resultados mostraram baixa riqueza de espécies, a qual esteve associada à população mono-específica de Chlorella sp. A densidade dos protozoários foi inversamente proporcional à densidade das clorofíceas na LAT (que apresentou altas concentrações de DQO, nitratos e nitritos e SS) e na LAG (com baixas concentrações de DQO solúvel e $O D)$. Constatou-se que a maior diversidade de espécies ocorreu nas últimas lagoas da série (LM2 e LAG), onde havia baixa concentração de nutrientes (compostos nitrogenados e fósforo total). As clorofíceas apresentaram a maior densidade relativa (> 97\%). O índice de Jaccard atingiu 100\% somente quando Chlorella $s p$ e, às vezes, diatomáceas foram encontradas na entrada e na saída do sistema (A ou B). A produtividade da biomassa algal foi em torno de $10 \mathrm{gSST} / \mathrm{m}^{2} / \mathrm{dia}$ na LAT, $8 \mathrm{gSST} / \mathrm{m}^{2} / \mathrm{dia}$ na LAG e inferior nas outras lagoas. O coeficiente de variação $(\mathrm{CV})$ das clorofíceas variou entre $0 \mathrm{e}$ 1,5 nas lagoas LAT e LAG, porém manteve-se constante em 0,9 até a $10^{\text {a }}$ semana na LM1 e em torno de 0,5 durante todo o período experimental na LM2; para a clorofila $a$, este coeficiente apresentou-se muito variável em todas as lagoas.

\section{REFERENCES}

APHA. AWWA. WEF. (1998) Standard Methods for the Examination of Water and Wastewater. $20^{\text {th }}$ Ed., Washington, DC, American Public Health Association.

Athayde, S.T.S.; Pearson, H.W.; Silva, S.A.; Mara, D.D.; Athayde Júnior, G.B.; Oliveira, R. (2000) Algological Study in Waste Stabilization Ponds. In: $1^{\text {st }}$ IWA Conferencia Latinoamericana en Lagunas de Estabilización y Reuso. Santiago de Cali, Colômbia.

Aguirre, P.; García, J.; Álvarez, E. (2004) Efficiency and design considerations of high rate ponds used for the treatment of piggery wastes. In: $6^{\text {th }}$ International Conference on Waste Stabilization Ponds and $9^{\text {th }}$ International Conference on Wetland Systems. Avignon, France, 131-138.

Bassères, A. (1990) Performance des microphytes et des macrophytes dans l'épuration d'effluents organiques à forte charge em ammoniaque. 
Toulouse, France: Université Paul Sabatier. (Thèse de Doctorat).

Costa, R. H. R.; Medri, W.; Perdomo, C. C. (2000) High-rate pond for treatment of piggery wastes. Wat. Sci. Tech., 42,10-11, 357- 362.

Costa, R.H.R., Oliveira, P.J.P., Oliveira, P.A.V., Souza, D. and Picot, B. (2002) High rate algal pond and maturation pond for the treatment of piggery wastes. In: $5^{\text {th }}$ International IWA Specialist Group Conference on Waste Stabilization Ponds: Pond Technology for the New Millennium. Auckland, New Zealand.

Cromar, N.J. and Fallowfield, H.J. (2003) Use of image analysis to determine algal and bacterial biomass in a high rate algal pond following Percoll fractionation. Wat. Sci. Tech., 48, 2, 53-60.

Cruz, L. S.; Dias Jr., C.; Keller, R.; Cassini, S. T. A.; Gonçalves, R. F. (2005) Variações temporais do fitoplâncton e de parâmetros físico-químicos em lagoas de estabilização facultativas tratando esgotos sanitários em regime de batelada. In: XXIII Congresso Brasileiro de Engenharia Sanitária $e$ Ambiental, ABES (Org.), Campo Grande, MS.

Estrada, V. E. E.; Hernández, D. E. A. (2002) Treatment of piggery wastes stabilization Ponds. Wat. Sci. Tech., 45, 1, 55-60.

Garcia, J.; Mujeriego, R.; Hernández, D.; Mariné, M. (2002) Long term diurnal variations on contaminant removal in high rate ponds treating urban wastewater. In: $5^{\text {th }}$ International IWA Specialist Group Conference on Waste Stabilization Ponds: Pond Technology for the New Millennium. Auckland, New Zealand.

Håkanson, L.; Malmaeus, J. M. ; Bodemer, U.; Gerhardt, V. (2003) Coefficients of variation for chlorophyll, green algae, diatoms, cryptophytes and blue-greens in rivers as a basis for predictive modelling and aquatic management. Ecological Modelling, 169, 179-196.

König, A. (2000) Biologia de las lagunas de estabilización: algas. In: Sistemas de Lagunas de Estabilization: como utilizar aguas residuales tratadas en sistemas de regadio. Mendonça, S. R. (Coord.). McGrawHill, 44-67.

Margalef, R. (1983) Limnología. Ed. Omega, Barcelona.

Maizonave, C. R. M.; Bendati, M. M.; Werner, V. R.; Cybis, L. F. A.; Carvalho, E. N. (2005) Avaliação planctônica do Reservatório da Lomba do Sabão (Porto Alegre, RS) com ênfase na ocorrência de cianobactérias: implicações para o abastecimento público. In: XXIII Congresso Brasileiro de Engenharia Sanitária e Ambiental, ABES (Org.), Campo Grande, MS.
Nusch, E. A. (1980) Comparation of different methods for clorophyll and phaeopigment determination. Arch. Hydrobiol. Beih. Stuttgart, 14, 14-36.

Odum, E. P. (1988) Ecologia. Ed. Guanabara, Rio de Janeiro, RJ.

Oliveira, P. J. P. (2002) Tratamento secundário $e$ terciário de dejetos de suínos utilizando lagoas de alta taxa algal, aerada e maturação. Florianópolis, UFSC. (Dissertação de Mestrado).

Oswald, W. J. (1988) Micro-algae and waste-water treatment. In: Micro-algal biotechnology. ED. Borowitzka and Borowitzka, Cambridge University Press, Cambridge, Great Britain, 305-328.

Picot, B.; Bahlaoui, A.; Moersidik, S.; Baleux, B.; Bontoux, J. (1992) Comparison of the purifying efficiency of high rate algal pond with stabilization pond. Wat. Sci. Tech., 25, 12, 197-206.

Sevrin-Reyssac, J.; La Noüe, J. ; Proulx, D.(1995) Le recyclage du lisier de porc par lagunage. Lavoisier, Paris : Technique and Documentation. 18p.

Suetmasu, G. L. (1995) Aspectos generales y principios básicos de los sistemas de lagunas de estabilización. In: Seminario Internacional de Lagunas de Estabilización, Colombia, 3-12.

Takahashi, M.; Ichimura, S. (1968) Vertical distribution and organic matter production of photosynthetic sulfur bacteria in japanese lakes. Limnol. Oceanogr., 13, 644-655.

Takahashi, M.; Ichimura, S. (1970) Photosynthetic properties and groth of photosynthetic sulfur bacteria in lakes. Limnol. Oceanogr., 15, 929-944.

Zanotelli, C.T. (2002) Modelagem matemática de nitrogênio e fósforo em lagoas facultativas e de aguapés para tratamento de dejetos de suínos. Florianópolis : UFSC. (Tese de Doutorado).

Zanotelli, C. T.; Medri, W.; Perdomo, C. C.; Mullinari, R.; Belli Filho, P.; Costa, R.H.R. (2002) The Perfomance of a Facultative Lagoon with Baffles in the Treatment of Swine Wastes. Wat. Sci. Tech., 45,1, 49-53.

Zulkifli, H. (1992) Traitement des eaux usées par lagunage à haut rendement: structure et dynamique des peuplements phytoplanctoniques. Montpellier, France: Université Montpellier I. (Thèse de Doctorat). 